\title{
Plate method for the determination of the normal serum bacteriostatic activity against staphylococci ${ }^{1}$
}

\author{
J. CYBULSKA AND J. JELJASZEWICZ \\ From the Department of Bacteriology, State Institute of Hygiene, Warsaw, \\ and the Department of Medical Microbiology, University Medical School, Warsaw, Poland
}

SYNOPSIS The growth of 100 staphylococcal strains in normal rabbit serum was studied. Determinations were carried out by the tube method previously described and by a new plate method, and the results agreed in both cases. The strains of staphylococci used differed in the production of bound coagulase, clumping factor, and staphylokinase, and exhibited different phage patterns. Their multiplication in serum was not dependent on any of the above-mentioned characteristics. The newly elaborated plate test is characterized by easy and quick performance and allows for the determination of 25 to 36 strains on one Petri plate.

Fresh sera from the majority of mammals exhibit bacteriostatic activity against non-pathogenic strains of Staphylococcus aureus while potentially pathogenic strains of this microorganism are resistant and multiply readily. This phenomenon, differing from the bactericidal activity of serum for other bacteria, has been recently investigated in some detail (Cybulska and Jeljaszewicz, 1965). During this study, some evidence was obtained indicating that serum bacteriostatic systemic activity may present a much more sensitive index of potential pathogenicity for staphylococci than the coagulase test. However, the tube method for determining activity in serum is laborious and is not very suitable for routine work. This paper presents a new plate method for determining serum bacteriostatic activity against staphylococci.

\section{MATERIALS AND METHODS}

DETERMINATION OF COAGULASE PRODUCTION This was done at temperatures of $20^{\circ} \mathrm{C}$. and $37^{\circ} \mathrm{C}$. with rabbit plasma. Fresh citrate plasma, diluted 1:5 with saline, was used. Results were read after one, three, six, and 24 hours' incubation in a water bath. Clumping factor was tested with undiluted plasma. Details of the techniques have already been described (Jeljaszewicz, 1958).

DETERMINATION OF STAPHYLOKINASE PRODUCTION The plate method proposed by Glanville (1964) was applied.

${ }^{1}$ This study was supported by research grant CDC-LP-3 from the Communicable Disease Center, U.S. Public Health Service.

Received for publication 15 June 1965.
BACTERIOPHAGE TYPING This was carried out with the set of bacteriophages received from the Central Public Health Laboratory, London, using a method described by Blair and Williams (1961).

SERUM Rabbit blood taken by heart puncture was placed at $37^{\circ} \mathrm{C}$. for one hour and then for two hours at $4^{\circ} \mathrm{C}$. The clot was removed and after centrifugation the serum was used during the next few hours. A pool of sera from at least three rabbits was used for each experiment.

TUBE DETERMINATION OF SERUM BACTERIOSTATIC ACTIVITY This was done as described previously (Cybulska and Jeljaszewicz, 1965).

PLATE METHOD Five per cent Oxoid agar in distilled water was sterilized in the autoclave. To $16 \mathrm{ml}$. of sterile and fresh rabbit serum heated to $40^{\circ} \mathrm{C} .4 \mathrm{ml}$. of agar was added, which had been melted beforehand and cooled to the same temperature. After thorough mixing the medium was poured onto Petri plates, $10 \mathrm{~cm}$. diameter. Cooled plates were then dried at $37^{\circ} \mathrm{C}$. for two hours. The inoculum of a strain to be tested was prepared as follows: an 18-hour broth culture was centrifuged, the sediment taken in $5 \mathrm{ml}$. of saline, and, after mixing, diluted a thousand times with saline. The resulting suspension was used for inoculation, using a loop or capillary pipette of the serum agar, and for a control agar with $3 \%$ sheep blood added. Strains sensitive to the bacteriostatic action of serum did not grow on serum agar, but multiplied on the blood agar. The typical picture of serum plate and blood agar inoculated with growing and inhibited staphylococci is presented in Figures 1 and 2. It should be added that staphylococci excreting beta-haemolysin produce characteristic opacity 


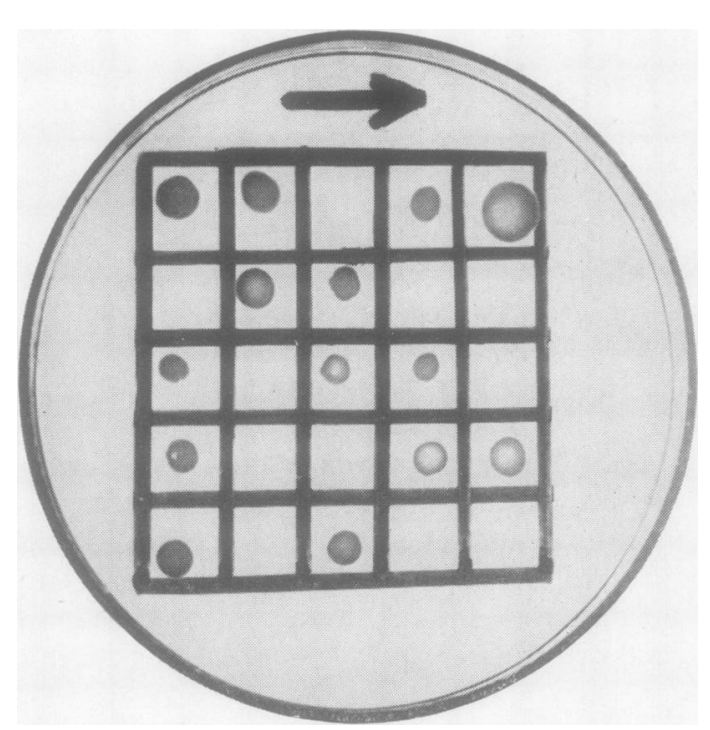

FIG. 1. Growth of 25 strains of staphylococci on the serum plate.

in serum. Strains producing this toxin and not multiplying in serum may evoke turbidity in serum agar, suggesting growth.

\section{RESULTS}

The results of determinations of bacteriostatic activity of serum against 100 different strains of staphylococci are presented in Table I. Both methods were used for these determinations. Strains differed in the presence of coagulase, clumping factor, and staphylokinase. These strains, as may be seen from Table II, belong also to different phage groups, and were received from various sources and several laboratories throughout the world.

Determinations made by tube and the new plate method resulted in complete agreement. Growth in serum was not dependent on excreted coagulase, clumping factor, or staphylokinase. Strains, being coagulase-negative and

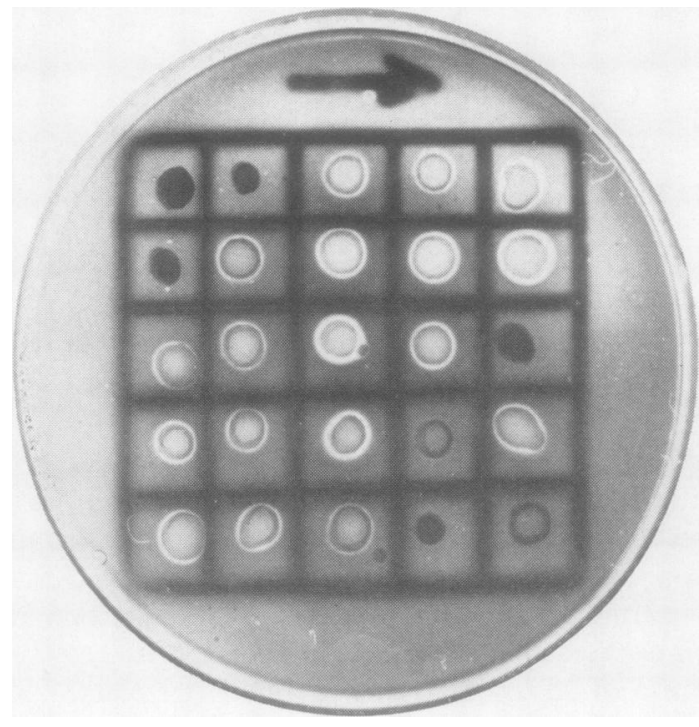

FIG. 2. Growth of 25 strains of staphylococci (control for serum plate) on blood agar.

clumping-factor-positive, grew easily in serum. Another strain, not producing any of these factors was found and also multiplied readily. Other variants isolated from pathological material, for example, strains which were coagulase- and clumping-factor-negative but staphylokinase-positive or coagulase- and staphylokinasenegative but clumping factor-positive, grew in serum as typical coagulase-positive strains. Ability to grow in serum was unconnected with the phage group. It is interesting to note that five out of six coagulase-negative but clumping-factor-positive strains typed with bacteriophages.

\section{DISCUSSION}

The bacteriostatic activity of normal rabbit serum may be tested by a plate method, which presents a

TABLE I

COMPARISON OF TUBE AND PLATE DETERMINATIONS OF SUSCEPTIBILITY OF STAPHYLOCOCCI TO THE BACTERIOSTATIC ACTIVITY OF NORMAL RABBIT SERUM

\begin{tabular}{|c|c|c|c|c|c|c|c|}
\hline \multirow{2}{*}{$\begin{array}{l}\text { Free Coagulase, Clumping } \\
\text { Factor, and Staphylokinase } \\
\text { Patterns }\end{array}$} & \multicolumn{2}{|c|}{ No. of Strains (Tube Method) } & \multicolumn{2}{|c|}{ No. of Strains (Plate Method) } & \multicolumn{2}{|c|}{ Comparison of Two Methods } & \multirow{2}{*}{$\begin{array}{l}\text { No. of Strains } \\
\text { Giving Variable } \\
\text { Results }\end{array}$} \\
\hline & Growth & No Growth & Growth & No Growth & Agreed & Not Agreed & \\
\hline $\mathrm{FC}+, \mathrm{CF}+, \mathrm{SK}+$ & 67 & - & 68 & - & 67 & - & 1 \\
\hline $\mathrm{FC}-, \mathrm{CF}+, \mathrm{SK}+$ & 5 & - & 5 & - & 5 & - & - \\
\hline $\mathrm{FC}+, \mathrm{CF}-, \mathrm{SK}+$ & 7 & - & 7 & - & 7 & - & 一 \\
\hline $\mathrm{FC}-\mathrm{CF}-, \mathrm{SK}+$ & 1 & - & 1 & - & 1 & - & - \\
\hline $\mathbf{F C}+, \mathbf{C F}+, \mathrm{SK}-$ & 2 & - & 2 & - & 2 & - & - \\
\hline $\mathrm{FC}-, \mathrm{CF}+, \mathrm{SK}-$ & 1 & 2 & 1 & 2 & 3 & - & - \\
\hline $\mathrm{FC}+, \mathrm{CF}-, \mathrm{SK}-$ & - & - & 2 & - & - & - & 2 \\
\hline $\mathrm{FC}-, \mathrm{CF}-, \mathrm{SK}-$ & 1 & 11 & 1 & 11 & 12 & - & - \\
\hline Totals & 84 & 13 & 87 & 13 & 97 & - & 3 \\
\hline
\end{tabular}


TABLE II

PHAGE PATTERN, COAGULASES, AND BACTERIOSTATIC ACTIVITY OF NORMAL RABBIT SERUM AGAINST STAPHYLOCOCCI

\begin{tabular}{|c|c|c|c|c|c|c|c|c|c|c|c|c|}
\hline \multirow[t]{2}{*}{ Phage Group } & \multicolumn{3}{|c|}{$\begin{array}{l}\text { Free Coagulase }+ \text { and } \\
\text { Clumping Factor }+\end{array}$} & \multicolumn{3}{|c|}{$\begin{array}{l}\text { Free Coagulase + and } \\
\text { Clumping Factor - }\end{array}$} & \multicolumn{3}{|c|}{$\begin{array}{l}\text { Free Coagulase }- \text { and } \\
\text { Clumping Factor }+\end{array}$} & \multicolumn{3}{|c|}{$\begin{array}{l}\text { Free Coagulase - and } \\
\text { Clumping Factor - }\end{array}$} \\
\hline & Typable & Growth & $\begin{array}{l}\text { No } \\
\text { Growth }\end{array}$ & Typable & Growth & $\begin{array}{l}\text { No } \\
\text { Growth }\end{array}$ & Typable & Growth & $\begin{array}{l}\text { No } \\
\text { Growth }\end{array}$ & Typable & Growth & $\begin{array}{l}\text { No } \\
\text { Growth }\end{array}$ \\
\hline I & 8 & 8 & & 2 & 2 & & 2 & 2 & & & & \\
\hline II & 3 & 3 & & & & & & & & & & \\
\hline III & 30 & 30 & & 3 & 3 & & 2 & 2 & & & & \\
\hline IV & 1 & 1 & & & & & & & & & & \\
\hline Miscellaneous & 1 & 1 & & & & & 1 & 1 & & & & \\
\hline Other $/ 80 / 81$ & 1 & 1 & & & & & & & & & & \\
\hline I and miscellaneous & 1 & Variable & & & & & & & & & & \\
\hline I and III & 1 & 1 & & & & & & & & & & \\
\hline Not typable & - & 24 & & - & 2 & & - & 1 & 2 & - & 2 & 10 \\
\hline II and III & & & & & & & & & & 1 & & 1 \\
\hline Totals & 46 & $69+1$ & & 7 & 7 & & 5 & 6 & 2 & 1 & 2 & 11 \\
\hline
\end{tabular}

simple test for the determination of potentially pathogenic staphylococci. Attention should be paid to the proper preparation of the inocula, as too heavy a suspension may result in false results. On one Petri plate 25 to 36 strains may be tested. Accuracy of the plate test is high as seen from a comparison with the tube method.

Large amounts of serum appear to be needed for the plate test $(16 \mathrm{ml}$. for one Petri plate) but to determine bacteriostatic activity by the tube method according to the number of strains to be tested on one plate, 12.5 to $18 \mathrm{ml}$. of serum is needed and the laboriousness of the plate method is incomparably less.

It has been shown by Włodarczak and Jeljaszewicz (1959) and Cybulska and Jeljaszewicz (1965) that coagulase does not play the decisive role in the bacteriostatic action of serum on staphylococci as was suggested by Ekstedt (1956a, b) and Ekstedt and Nungester (1955). Purified preparations of coagulase did not abolish the bacteriostatic activity of sera; even in this study seven coagulase-negative strains of Staphylococcus aureus were presented which multiply in serum as typical coagulase-positive strains. The same criteria may be applied to the production of staphylokinase or the phage pattern.

Sometimes, coagulase-negative and clumpingfactor-negative strains, or staphylococci producing the last factor only, are undoubtedly isolated as causes of infection. On the basis of the coagulase test they are recognized as saprophytic. It seems therefore that the determination of the bacteriostatic activity of rabbit or human serum against staphylococci may be considered as an equal or even better test than the coagulase determination for the evaluation of potentially pathogenic staphylococci.

\section{REFERENCES}

Blair, J. E., and Williams, R. E. O. (1961). Bull. Wld Hlth Org., 24, 771 Cybulska, J., and Jeljaszewicz, J. (1965). J. Bact., in the press. Ekstedt, R. D. (1956a). Ibid., 72, 157.

- (1956b). Ann. N.Y. Acad. Sci., 65, 119.

- and Nungester, W. J. (1955). Proc. Soc. exp. Biol. (N. Y.), 89, 90. Glanville, K. L. A. (1964). Personal communication.

Jeljaszewicz, J. (1958). Acta microbiol. pol., 7, 17.

Włodarczak, K., and Jeljaszewicz, J. (1959). Nature (Lond.), 184, 1514. 